\title{
Obesity and Type 2 Diabetes Prevalence in Adults from Two Remote First Nations Communities in Northwestern Ontario, Canada
}

\author{
Pascal Imbeault, ${ }^{1}$ François Haman, ${ }^{2}$ Jules M. Blais, ${ }^{3}$ Shinjini Pal, ${ }^{2}$ Tim Seabert, ${ }^{3}$ \\ Eva M. Krüimmel, ${ }^{3}$ and Michael A. Robidoux ${ }^{2}$ \\ ${ }^{1}$ Behavioral and Metabolic Research Unit, School of Human Kinetics, Faculty of Health Sciences, University of Ottawa, \\ 125, University Street (room 350), Ottawa, ON, Canada K1N 6N5 \\ ${ }^{2}$ Indigenous Health Group, School of Human Kinetics, Faculty of Health Sciences, University of Ottawa, Ottawa, \\ ON, Canada K1N 6N5 \\ ${ }^{3}$ Department of Biology, University of Ottawa, Ottawa, ON, Canada K1N 6N5
}

Correspondence should be addressed to Pascal Imbeault, imbeault@uottawa.ca

Received 2 December 2010; Revised 21 January 2011; Accepted 15 February 2011

Academic Editor: Renato Pasquali

Copyright (C) 2011 Pascal Imbeault et al. This is an open access article distributed under the Creative Commons Attribution License, which permits unrestricted use, distribution, and reproduction in any medium, provided the original work is properly cited.

\begin{abstract}
Objective. To assess the prevalence rates of obesity and type 2 diabetes in adults from two First Nations communities in northwestern Ontario, Canada. Methods. Body weight, height, and waist circumference as well as fasting and postprandial glucose levels following an oral glucose tolerance test were measured in 31 men and 41 women. Results. The mean age of the sample was $43 \pm 13 \mathrm{y}$. The prevalence of obesity was $65.3 \%$ and was comparable between men and women. $90.3 \%$ of the individuals presented waist circumference levels greater than the thresholds associated with an increased risk of developing health problems. 26 of the 72 individuals $(36.1 \%)$ were found to be type 2 diabetic. The prevalence of diabetes was not different between men and women. Conclusion. Using objective measurements, this study confirms that First Nations adults from remote communities of Canada continue to experience a disproportionately higher prevalence of obesity and type 2 diabetes than nonaboriginal Canadians.
\end{abstract}

\section{Introduction}

An excess of body weight, commonly referred to as obesity, has reached epidemic proportions in different segments of the population around the world [1]. In Canada, the obesity prevalence has risen steadily during the last 25 years, with $23 \%$ of adults being classified as obese according to the latest Canadian Community Health Surveys [2, 3]. Recent reports arising from the same community survey highlight the greater prevalence of obesity in off-reserve aboriginal population (i.e., 38\%) compared to the rest of the adult population $[4,5]$.

Amongst Canadian aboriginals, who constitute 3.4\% ( 1 million people) of the Canadian population, First Nations Peoples (First Nations peoples: according to the glossary of the Indian and Northern Affairs of Canada (http://www .ainc-inac.gc.ca/ap/tln-eng.asp), this term refers to Canada's population formerly defined as "Indian" under the 1876 Indian Act.) represent the country's largest aboriginal group (64\% registered (Registered First Nations: according to the glossary of the Indian and Northern Affairs of Canada (http://www.ainc-inac.gc.ca/ap/tln-eng.asp), this term refers to Persons registered under the Indian Act of Canada.) and nonstatus First Nations versus 30\% Métis and 4\% Inuit) [6]. The First Nations Regional Longitudinal Health Survey 2002/03 collected data on self-reported heights and weights from on-reserve First Nations populations and showed that the overweight and obesity prevalence was also disproportionally higher in adult First Nation $(\sim 73 \%)$ than the general population $(\sim 50 \%)$ [7]. This high prevalence of obesity 
among First Nations was identified to be partly responsible for the greater prevalence of self-reported diabetes in this population. While this survey highlights a significant existing problem that obesity and diabetes disproportionately affect First Nations adults, this population is generally understudied. Also, many of the studies conducted are limited by the reliance of self-reported data. Using ethnographic [8] and objective clinical measures, the aim of this study was to describe the prevalence of overweight/obesity as well as type 2 diabetes in First Nations (Oji-Cree) adults living in two remote communities from northwestern Ontario, Canada.

\section{Methods}

All research activities underwent ethics review and were approved by both the University of Ottawa's and Health Canada's Research Ethics Boards.

2.1. Community Profiles and Participants. Wapekeka First Nation (Angling Lake) is located $26 \mathrm{~km}$ Northwest of Kitchenuhmaykoosib Inninuwug (Big Trout Lake) and $451 \mathrm{~km}$ northeast of Sioux Lookout in northwestern Ontario. The population is comprised of approximately 363 Band Members (Band Members: according to the glossary of the Indian and Northern Affairs of Canada (http://www.aincinac.gc.ca/ap/tln-eng.asp), this term refers to a body of First Nations for whose collective use and benefit lands have been set apart or money is held by the Crown, or declared to be a band for the purposes of the Indian Act. Each band has its own governing band council, usually consisting of one chief and several councilors. Community members choose the chief and councilors by election, or sometimes through custom. The members of a band generally share common values, traditions, and practices rooted in their ancestral heritage.) with the majority (328) of the members living on reserve. Kasabonika Lake First Nation is located approximately $30 \mathrm{~km}$ south of Wapekeka on the Asheweig River. The population is comprised of approximately 856 Band Members with the majority (791) of the members living on reserve. Both Wapekeka and Kasabonika are accessible year-round by air; during the winter months the communities are accessible by a winter-road constructed over the snow and ice. The main languages spoken are OjiCree and English.

A total of 83 people were recruited and interviewed through the assistance of local research coordinators and translators who were hired over the course of the study. Participants were recruited based on self-described dietary behaviour as either relying predominantly on landbased food items (primarily wild game) or predominantly market foods. Semistructured interviews and participation/observation in daily food practices assisted in determining dietary behaviour of participants. A relative Wild Food Index was designed to represent a range of wild food consumption, with 100 at the top and 0 at the bottom. 100 represents the maximum level of wild food consumption, meaning people who eat entirely from wild food sources. The opposite end of the scale represents people who never eat wild food. There was no one from either community who ate only wild food or store bought food. Rather, there was a continuum of wild food consumption frequency consumers in our samples. In both communities, 72 agreed to be research participants in the study. The inclusion criteria were that a person must be Aboriginal, over 18 years of age, not pregnant, and free of type 1 diabetes. Most recent data from Indian and Northern Affairs Canada indicates that $50 \%$ of Wapekeka's population (164 people) is over 19 years of age [9]. Therefore the 39 volunteers from Wapekeka made up approximately $24 \%$ of the eligible population. Similarly, $47 \%$ (372 people) of Kasabonika's population is over 19 [10], and thus, the 33 participants made up approximately $9 \%$ of the eligible population.

\subsection{Anthropometric and Insulin Sensitivity Assessments.} Once interview and ethnographic dietary surveys were completed in late September 2007, two research teams visited the two communities to conduct the clinical research between late September and early November. Briefly, participants were asked to report at nursing stations/clinic located in each community in the morning following $24 \mathrm{~h}$ without heavy physical activity and after a $12 \mathrm{~h}$ fast. A total of 33 participants completed the clinical trial in Kasabonika and 39 participants completed the trial in Wapekeka.

Body weight was determined with a standard beam scale and height and waist circumference were measured with a measuring tape. Body weight was measured after having removed shoes. Height was measured with the participant's bare feet together, with heels, buttocks, back, and head against the wall, and following a normal inspiration. Based on the Canadian guidelines for body weight classification in adults [11], body mass index (BMI), defined as body weight in kilograms divided by square height in meters, was used to categorize an individual as underweight/normal weight $\left(\mathrm{BMI}<25 \mathrm{~kg} / \mathrm{m}^{2}\right)$, overweight $\left(25 \mathrm{~kg} / \mathrm{m}^{2} \leq \mathrm{BMI} \leq\right.$ $\left.29.9 \mathrm{~kg} / \mathrm{m}^{2}\right)$ or obese $\left(\mathrm{BMI} \geq 30 \mathrm{~kg} / \mathrm{m}^{2}\right)$. Waist circumference was measured, in duplicate (and averaged) at the midpoint between the last floating rib and the top of the iliac crest [11].

\subsection{Oral Glucose Tolerance Test. A $2 \mathrm{~h}$ OGTT was performed} using a $75 \mathrm{~g}$ solution of glucose. Participants were asked to fast for $12 \mathrm{~h}$ and to refrain from any exercise proceeding the OGTT session. It was also requested that they do not smoke or drink anything but water before their sessions. If they had taken any medication in twelve hours preceding the OGTT, this was also noted. After glucose ingestion, blood samples were taken after 15, 30,60, and $120 \mathrm{~min}$ for analysis of plasma glucose and insulin concentrations. Upon collection, samples were immediately centrifuged at $3500 \mathrm{rpm}$ and plasma was temporarily stored at $-20^{\circ} \mathrm{C}$ in the clinics, before being transferred to the laboratory where they were stored at $-80^{\circ} \mathrm{C}$ for future assays.

Glucose concentrations were assayed using spectrophotometric analysis $(340 \mathrm{~nm})$ after conversion of glucose to glucose 6-phosphate by hexokinase and insulin levels were analyzed by a commercially available enzyme-linked immunosorbent assay (ELISA) kit (Millipore, Billerica, MA, USA), as previously described [12]. Based on the report of 
TABLE 1: Descriptive characteristics of First Nations adults from two northwestern communities of Ontario, Canada.

\begin{tabular}{lcc}
\hline & $\begin{array}{c}\text { Men } \\
(n=31)\end{array}$ & $\begin{array}{c}\text { Women } \\
(n=41)\end{array}$ \\
\hline Age (year) & $42 \pm 12$ & $43 \pm 13$ \\
Weight $(\mathrm{kg})$ & $97 \pm 17$ & $84 \pm 14^{*}$ \\
BMI $\left(\mathrm{kg} / \mathrm{m}^{2}\right)$ & $31.4 \pm 4.5$ & $32.6 \pm 5.1$ \\
Waist circumference $(\mathrm{cm})$ & $112 \pm 12$ & $114 \pm 14$ \\
\hline
\end{tabular}

Data are expressed as means \pm standard deviation.

BMI = body mass index.

* Significantly different from men at $P<.01$.

the expert committee on the diagnosis and classification of diabetes mellitus [13], participants with a fasting plasma glucose level greater than or equal to $7.0 \mathrm{mmol} / \mathrm{L}$ and/or a $2 \mathrm{~h}$ after glucose load level greater than or equal to $11.1 \mathrm{mmol} / \mathrm{L}$ were established type 2 diabetic $(n=26)$. The rest of the participants were considered nondiabetic $(n=46)$.

2.4. Statistical Analysis. The Student's $t$-test was utilized for comparisons between men and women' descriptive characteristics. The chi-square test of association was used to determine whether the prevalence rates of obesity, overweight/obesity, and diabetes were equally distributed between men and women. Alpha was set at 0.05. All analyses were performed using SPSS Software 16.0 (SPSS Inc. Chicago, Ill, USA).

\section{Results}

The descriptive characteristics of participants are presented in Table 1. The mean age was comparable between men and women. Body weight was significantly greater in men as compared to women $(P<.01)$. No significant difference was observed in body mass index and waist circumference between men and women.

3.1. Prevalence of Overweight/Obesity. In the total sample, the prevalence of obesity was $65.3 \%$ and the prevalence of overweight/obesity was $91.6 \%$ (Figure 1). There was no difference in the prevalence rates of obesity between men and women (men: $61.2 \%$ and women: $68.3 \%$ ) as well as in the prevalence rates of overweight/obesity (men: $90.3 \%$ and women: $92.7 \%)$.

3.2. Waist Circumference. As an indicator of health risk associated with excess abdominal adipose tissue, waist circumference was measured. In the total sample, $90.3 \%$ of the individuals exceeded thresholds (i.e., men $\geq 102 \mathrm{~cm}$, women $\geq 88 \mathrm{~cm}$ ) for risk of developing health problems such as type 2 diabetes, coronary heart disease, and hypertension. The proportion of individuals exceeding these thresholds did not differ between men (83.9\%) and women (90.3\%).

3.3. Prevalence of Type 2 Diabetes. Based on the glucose levels measured before and after 120 minutes of the oral glucose tolerance test, the prevalence of type 2 diabetes was also analyzed in our sample. Overall, 26 of the total 72 individuals

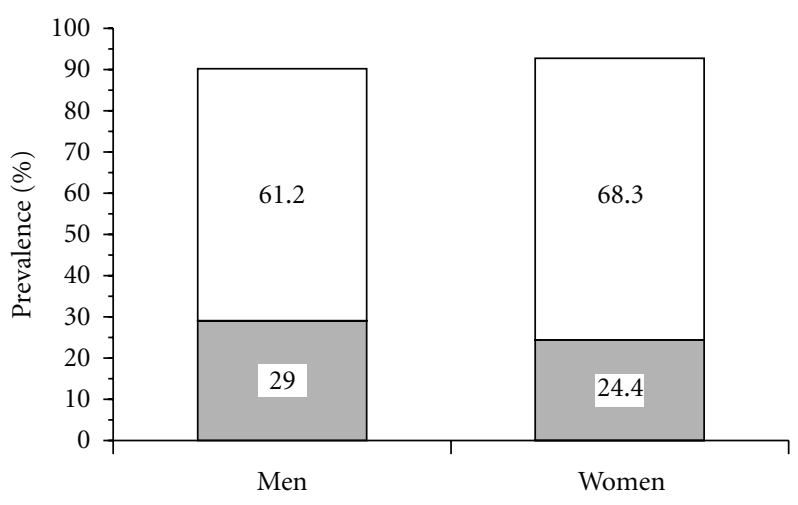

Obesity
Overweight

Figure 1: Prevalence of measured overweight $\left(25 \mathrm{~kg} / \mathrm{m}^{2} \leq\right.$ body mass index $\leq 29.9 \mathrm{~kg} / \mathrm{m}^{2}$ ) and obesity (body mass index $\geq 30$ $\mathrm{kg} / \mathrm{m}^{2}$ ) among men and women from two remote First Nations communities of northwestern Ontario, Canada.

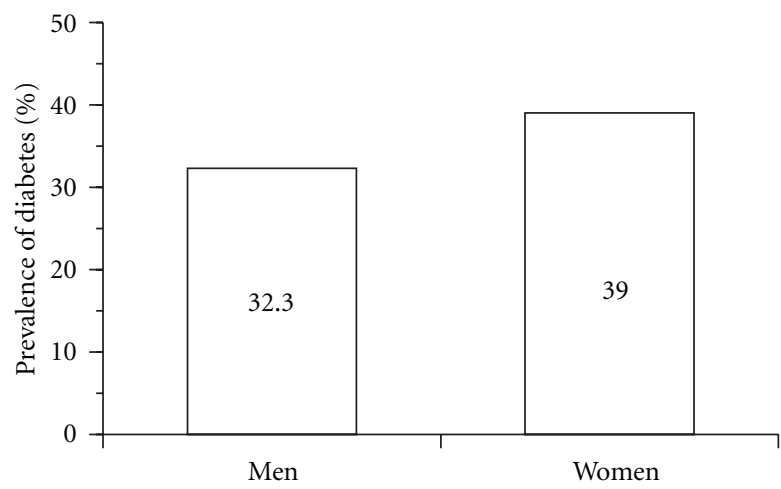

Figure 2: Prevalence of measured diabetes among men and women from two remote First Nations communities of northwestern Ontario, Canada. Diabetes was defined as fasting glucose levels $\geq$ to $7.0 \mathrm{mmol} / \mathrm{L}$ and/or a $2-\mathrm{h}$ post glucose load level $\geq 11.1 \mathrm{mmol} / \mathrm{L}$.

tested (i.e., 36.1\%) were considered type 2 diabetic according to the criteria of the expert committee on the diagnosis and classification of diabetes. No significant difference was found in the prevalence rates of type 2 diabetes between men $(32.3 \%)$ and women (39.0\%) (Figure 2). As compared to the medical records of the participants, the oral glucose tolerance test allowed us to identify 3 new cases of diabetes. 8 individuals were also identified with impaired glucose tolerance.

\section{Discussion}

The aim of the present study was to determine the prevalence of overweight/obesity as well as type 2 diabetes in First Nations adults living in northwestern communities of Ontario, Canada. Using measured heights and weights, our results indicated a prevalence of obesity and overweight/obesity of $65 \%$ and of $92 \%$, respectively. These levels were comparable in men and women. This high prevalence 
of obesity was also accompanied by an excess of abdominal adipose tissue, as indicated by the measurement of waist circumference which, in $90 \%$ of the sample, exceeded the thresholds for increased risk of health problems. Finally, using glucose levels measured before and after $2 \mathrm{~h}$ of an oral glucose tolerance test, we observed that $36.1 \%$ of our sample was type 2 diabetics.

An excess of adipose tissue is now well recognized as one of the most serious public health issues in the world [14] and will likely get worse because obesity rates are continuing to rise in most countries [1]. The results of the current study do confirm the high prevalence of obesity in First Nations adults from northwestern communities of Ontario. In fact, the prevalence of the whole sample studied was $65 \%$, which is almost twice as high as values reported in off-reserve Aboriginal individuals from the 2004 Canadian Community Health Survey (i.e., 38\%) [4, 5] and the 2002-2003 First Nations Regional Longitudinal Health Survey (36\%) [7], which represents on-reserve First Nations individuals of Canada. In addition, the results of our study confirm that the prevalence of obesity in these First Nations communities (i.e., 65\%) far exceeds that for nonaboriginals in Canada (i.e., 23\%) [3].

Adiposity has a potent negative effect on insulin sensitivity [15]. It is also well recognized that a specific excess of adipose tissue at the abdominal level predisposes one at a great risk of being characterized by insulin resistance $[16,17]$. We found that only 7 of the 72 individuals studied had waist circumference measurements, a proxy of abdominal fat, below thresholds for decreased risk of developing metabolic diseases. The prevalence of obesity in combination with high levels of abdominal adiposity, as indicated by the measurement of waist circumference, most likely explains the high rates of type 2 diabetes observed in our sample-1 out of 3 individuals were found with type 2 diabetic. This figure far exceeds the prevalence estimates of $8.3 \%$ of the Canadian population aged between 18 to 74 years reported in the most recent National Diabetes Surveillance System (2006-07 findings) [18]. Our results corroborate those of other studies reporting that diabetes [19-23] and other comorbidities such as dyslipidemia and hypertension [19] disproportionately affects young First Nations adults across Canada.

Some limitations and strengths of this study should be discussed. First, despite the fact that our sample size represents $9 \%$ and $24 \%$ of the eligible adult population in each community studied, we are aware that our findings highlights a specific remote area of northwestern Ontario and thus, could not be generalized to the entire population of First Nations in Canada. Second, some estimates of physical activity levels and energy intake would have been of merit. Finally, no cause-and-effect interpretation can be invoked between the high prevalence of obesity and type 2 diabetes in this sample because of the cross-sectional nature of the study. The results of the present study are also strengthened by different factors. First, anthropometric measurements were performed to objectively characterize the adiposity levels as well as the regional fat distribution of our participants. Second, an oral glucose tolerance test was used to identify people with diabetes instead of using selfreported information or fasting glucose levels only.
Whether or not obesity and its comorbidities occur in individuals and populations depend on biological, behavioral, and environmental factors. The question as to why there is such a high prevalence of obesity, along with a disproportionately high rate of diabetes in Canada's remote First Nations communities is not under the scope of this study but was recently reviewed by our group [24]. In summary, this study highlights the gravity of the problem of obesity and type 2 diabetes in First Nations adults. Efforts should now be directed at the individual and community levels to adopt and maintain healthy dietary and physical activity patterns to prevent further weight gain and, hopefully over time, to keep weight off.

\section{Acknowledgments}

The authors would like to thank Wapekeka and Kasabonika First Nations Chiefs and Councils for volunteering to participate in this study. They would like to thank the participants, research coordinators-Geraldine Brown and Barbara Cutfeet-Keith Mason, Laura Semple and family, Beatrice Anderson, Chris Anderson and family, and the host of other community members who made us feel so welcome throughout their stays in each community. They would like to thank the nurses and staff at the Nursing Station in Kasabonika and the Nursing clinic in Wapekeka. They are grateful to the Shibogama First Nations Council, in particular the Executive Director Margaret Kenequanash, and Director of Finance and Administration, Beverley Christink. Finally they would like to thank the Northern First Nations Environmental Contaminant Program for the generous funding that made this research possible.

\section{References}

[1] International association for the study of Obesity, "International Obesity Task Force prevalence data," 2010, http:// www.iotf.org/database/index.asp.

[2] P. T. Katzmarzyk and C. Mason, "Prevalence of class I, II and III obesity in Canada," Canadian Medical Association Journal, vol. 174, no. 2, pp. 156-157, 2006.

[3] M. Tjepkema, "Adult obesity," Health Reports, vol. 17, no. 3, pp. 9-25, 2006.

[4] D. Garriguet, "Obesity and the eating habits of the Aboriginal population," Health Reports, vol. 19, no. 1, pp. 21-35, 2008.

[5] P. T. Katzmarzyk, "Obesity and physical activity among aboriginal canadians," Obesity, vol. 16, no. 1, pp. 184-190, 2008.

[6] Statistics Canada, "Aboriginal population profile," 2010, http://www12.statcan.gc.ca/census-recensement/2006/dp-pd/ prof/92-594/details/page.cfm?Lang=E\&Geo1=PR\&Code $1=01$ $\&$ Geo2 $=$ PR \&Code $2=01 \&$ Data $=$ Count $\&$ SearchText $=$ canada $\&$ SearchType $=$ Begins $\&$ SearchPR $=01 \& B 1=$ All\&Custom $=$.

[7] First Nations Centre, First Nations regional longitudinal health survey (RHS) 2002/03: the people report. First Nations information governance committee, assembly of First Nations. First Nations Centre at the national Aboriginal health organization, 2005.

[8] M. A. Robidoux, M. Batal, P. Imbeault et al., "Traditional foodways in two contemporary northern First Nations 
communities," Canadian Journal of Native Studies, vol. 32, no. 2, 2012.

[9] Indian and Northern Affairs Canada. Canada, "Wapekeka First Nation Detail," 2008, http://pse5-esd5.ainc-inac.gc.ca/ fnp/Main/Search/FNPopulation.aspx?BAND_NUMBER=206 \&lang=eng.

[10] Indian and Northern Affairs Canada, "Kasabonika Lake First Nation Detail," 2008, http://pse5-esd5.ainc-inac.gc.ca/ fnp/Main/Search/FNPopulation.aspx?BAND_NUMBER=210 \&lang=eng.

[11] Canada, "Canadian guidelines for body weight classification in adults," O. o. N. P. a. Promotion. Ottawa, Health Canada, 2003.

[12] P. Imbeault, I. Dépault, and F. Haman, "Cold exposure increases adiponectin levels in men," Metabolism, vol. 58, no. 4, pp. 552-559, 2009.

[13] J. R. Gavin, K. G. M. M. Alberti, M. B. Davidson et al., "Report of the expert committee on the diagnosis and classification of diabetes mellitus," Diabetes Care, vol. 26, no. 1, pp. S5-S20, 2003.

[14] D. W. Haslam and W. P. T. James, "Obesity”, Lancet, vol. 366, no. 9492, pp. 1197-1209, 2005.

[15] B. B. Kahn and J. S. Flier, "Obesity and insulin resistance," Journal of Clinical Investigation, vol. 106, no. 4, pp. 473-481, 2000.

[16] J. P. Després, A. Nadeau, and A. Trembaly, "Role of deep abdomianl fat in the association between regional adipose tissue distribution and glucose tolerance in obese women," Diabetes, vol. 38, pp. 304-309, 1989.

[17] S. Fujioka, Y. Matsuzawa, K. Tokunaga, and S. Tarui, "Contribution of intra-abdominal fat accumulation to the impairment of glucose and lipid metabolism in human obesity," Metabolism, vol. 36, no. 1, pp. 54-59, 1987.

[18] Report from the National Diabetes Surveillance System: Diabetes in Canada, Public Health Agency of Canada, 2009.

[19] S. G. Bruce, N. D. Riediger, J. M. Zacharias, and T. K. Young, "Obesity and obesity-related comorbidities in a Canadian First Nation population," Preventing Chronic Disease, vol. 8, no. 1, pp. 1-8, 2011.

[20] M. L. Chateau-Degat, D. Pereg, G. M. Egeland et al., "Diabetes and related metabolic conditions in an aboriginal cree community of Quebec, Canada," Canadian Journal of Diabetes, vol. 33, no. 3, pp. 156-162, 2009.

[21] R. Dyck, N. Osgood, T. H. Lin, A. Gao, and M. R. Stang, "Epidemiology of diabetes mellitus among First Nations and non-First Nations adults," Canadian Medical Association Journal, vol. 182, no. 3, pp. 249-256, 2010.

[22] S. B. Harris, J. Gittelsohn, A. Hanley et al., "The prevalence of NIDDM and associated risk factors in native Canadians," Diabetes Care, vol. 20, no. 2, pp. 185-187, 1997.

[23] T. K. Young, J. Reading, B. Elias, and J. D. O’Neil, “Type 2 diabetes mellitus in Canada's First Nations: status of an epidemic in progress," Canadian Medical Association Journal, vol. 163, no. 5, pp. 561-566, 2000.

[24] F. Haman, B. Fontaine-Bisson, M. Batal, P. Imbeault, J. M. Blais, and M. A. Robidoux, "Obesity and type 2 diabetes in Northern Canada's remote First Nations communities: the dietary dilemma," International Journal of Obesity, vol. 34, supplement 2, pp. S24-S31, 2010. 


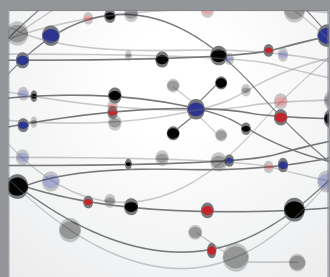

The Scientific World Journal
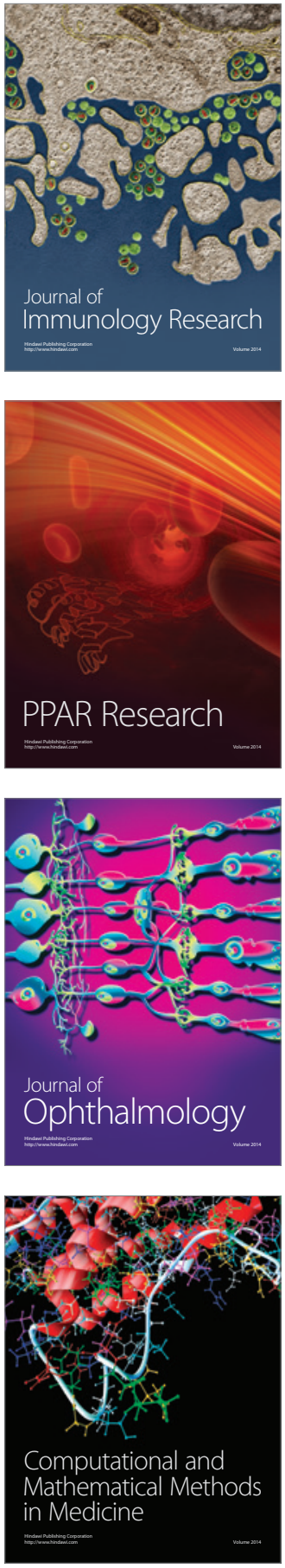

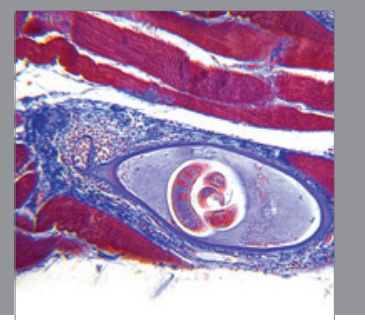

Gastroenterology

Research and Practice
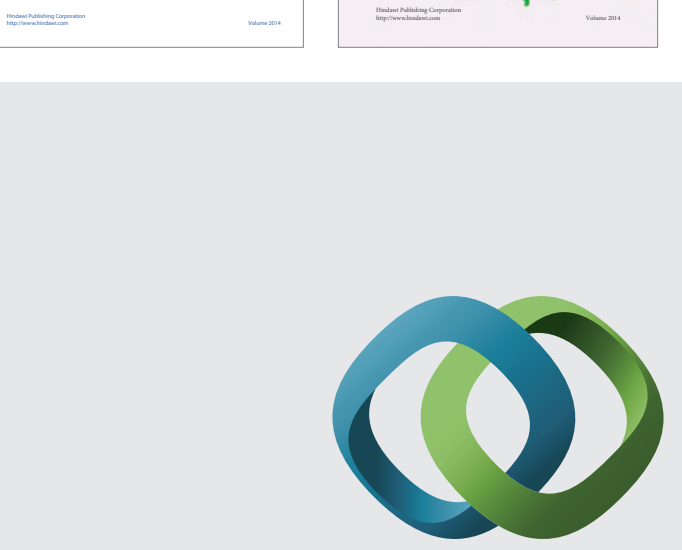

\section{Hindawi}

Submit your manuscripts at

http://www.hindawi.com
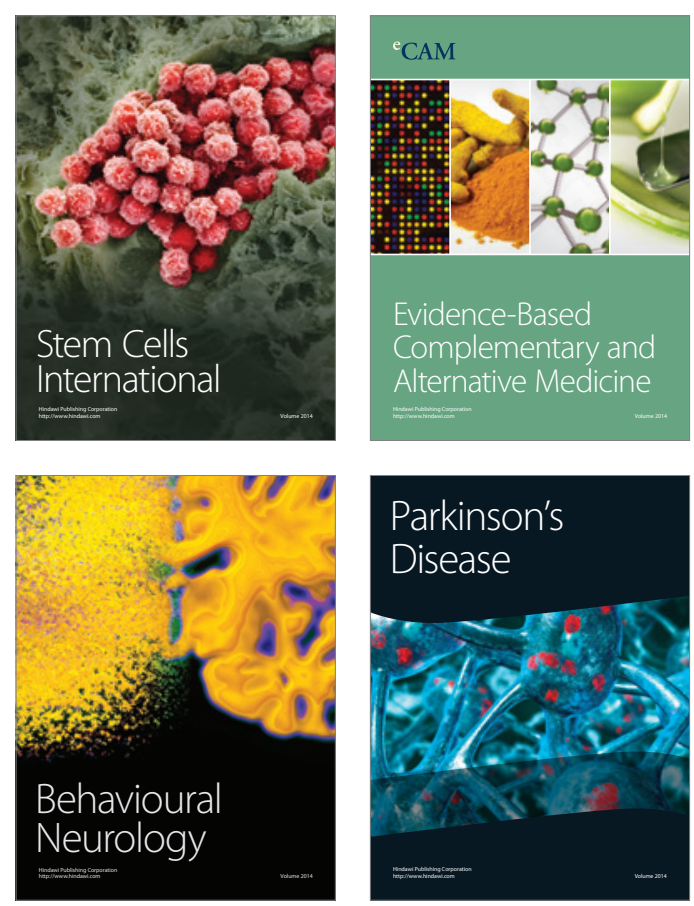

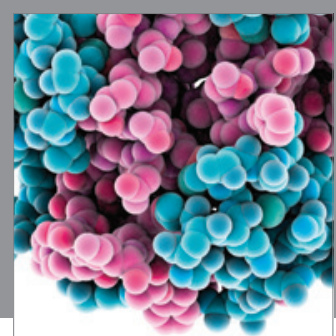

Journal of
Diabetes Research

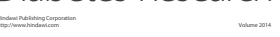

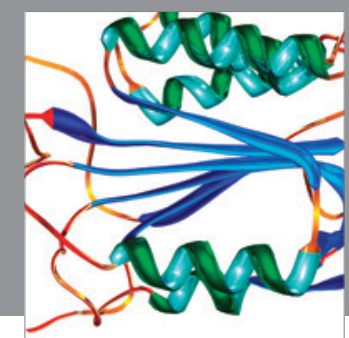

Disease Markers
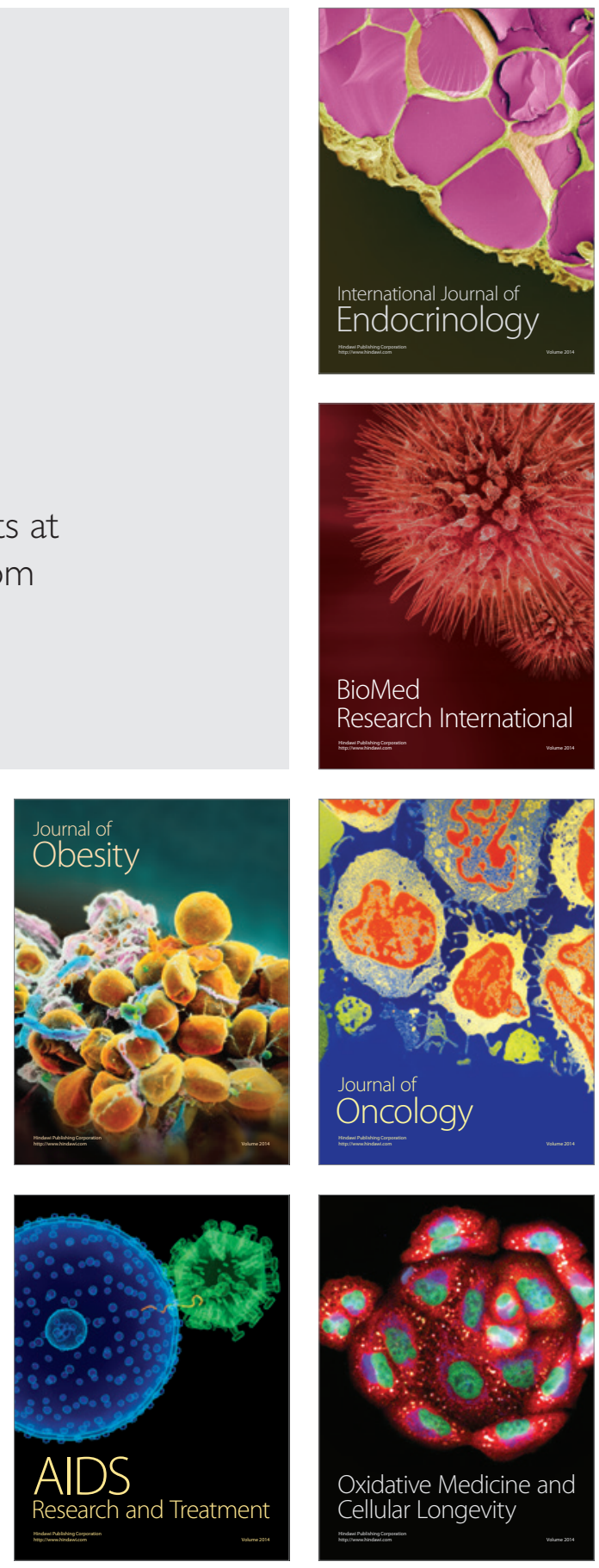